\title{
Protective Effect of Vitamin C and Glutathione Against the Histopathological Changes Induced by Imidacloprid in the Liver and Testis of Japanese Quail.
}

\author{
Omiama Soliman Eissa \\ National Center for Radiation Research and Technology
}

\begin{abstract}
Pesticides are double wedged weapons. They are considered to be the heavy cost of civilization. They are widely used in our daily life. Recently their effects on male fertility have attracted attention. One of these pesticides is imidacloprid. This work was designed to investigate the histological changes in liver and testis of Japanese quail treated with imidacloprid for different periods as well as the reversibility of such changes after arrest of the treatment for recovery period. The effect of vitamin $\mathrm{C}$ and glutathione as a protective agent against the action of imidacloprid on liver and testis was also determined.
\end{abstract}

\section{Introduction}

Pesticides are widely used for control of pests in many fields to protect public health, subsistence of crops, food and other materials essential to mankind and animals.

Imidacloprid is a new insecticide and it belongs to a new active group nitroguanidine. Many representatives of this class of compounds, imidacloprid in particular, have an excellent insecticide action (Brocksma et al. 1993). The action mechanism of imidacloprid differs not only from that of the organophosphorous compounds and carbametes, but also from that of the pyrethroids. (Soloway et al, 1978).

It is of interest to study the effect of imidacloprid on one of the most important economic birds, the Japanese quail (Couternix Couternix japonica). Dieher et al. (1991) found that after the discovery of the nitromethylene and chloropyridyl insecticidal compounds, which are considered as powerful insecticides and perform an important mechanism of action more over than phosphates, carbamates and pyrethroid insecticides groups. Another potent insecticides, in addition to the nitromethylene compounds, are the guanidine derivatives.
Among the various problems associated with pesticide use is the possibility of its biological accumulation which produces real problems, considering that many animal tissues and milk are ingested by human beings (Kutches et al., 1970), which may cause clinical and subclincal effects leading to loss in animal performance or in residual contamination of animal deviation which may later be consumed by humans (Ceron et al., 1995). Thus, the disappearance of pesticide residues at a given location does not mean the end of the problem, but it might be translocated, bioconcentrated or converted into more dangerous compounds (Matsumura, 1985).

Zafeiridon and Theophilids (2004), described the mode of action of imidacloprid as agonist on the nicotinic acetylcholine receptors of motor neuron, i.e. prevent the binding of acetylcholine to certain acetylcholine receptors (AchRs) by binding to these receptors themselves, in other words, imidacloprid acts as nicotinic acetylcholine receptors stimulator (nAchRs). The selectivity of this molecule and analogue may be due to the insensitivity of mammalian nicotinic 


\section{Omiama Soliman Eissa}

acetylcholine receptors (nAchRs) and the high sensitivity of analogous receptors in insects.

Imidacloprid recorded as one of the best protecting insecticide against ctenocephalides flea on cats and dogs, it provided a high level of residual activity in a very low time, either in laboratory condition or in home environment model (Dennis et al., 2000 \& Hutchinson et al., 2001) and Liburd et al., (2004).

Philippe et al. (1999), reported that when pigeon feed on potential ingestion of imidacloprid coated seeds, the primary metabolite shape of imidacloprid was 6chloronicotinic acid in the tissues and organs of affected animals. Birds found dead after exposure to imidacloprid, toxic residues detected in the liver of affected pigeons.

Pfluger and Schmuch (1991), studied the possibility of contact with the active substance, and hence the risk of side effects of imidacloprid insecticide is greatly restricted for many organisms in the environment. Imidacloprid has to be classified as toxic agent to birds with an LD50 ranges between $25-50 \mathrm{mg} / \mathrm{kg}$.

The mammalian toxicity of imidacloprid is low. The lowest LD50 value of $131-168 \mathrm{mg} / \mathrm{kg}$ was determined in mice. The subacute toxicity for a mammal is also outside the hazardous range. The reproduction toxicity in mammals is in the same favorable range as in birds. The risk of imidacloprid was increased during its application in a seed dressing or in granules more than the residues of spray application (Shull and Coheeke 1983).

Abbink (1991), discovered the properties of the new insecticide imidacloprid and its analogues and has shown that it had an excellent insecticidal action which can similarly be achieved by interfering with the postsynaptic receptors. It has been released into the synapse (the neurotransmitter cannot exert an effect unless it binds to the receptors in the postsynaptic membrane.).

Imidacloprid and its derivatives prevent the binding of acetylcholine to certain acetylcholine receptors by binding to those receptors themselves (Abbink, 1991).

Insecticides transformed into chemically reactive metabolites in the liver is either irreversibly binds to hepatic glutathione to be detoxicated or bind with hepatic proteins and produced hepatic toxicity. Then the hepatic glutathione content can be greatly depleted after exposure to insecticides, and this leads to damage of the hepatic tissues. Then the addition of external glutathione as antidotes may make a good protection against insecticide toxicity. (Abd-Elghaney 2002).

Glutathione acts as an antioxidant and protective agent against insecticide. Glutathione also plays an important role in removal of hydroperoxides and hence protection from ionizing radiation and its maintenance of the sulfohydryl status of proteins and transport of Y- glutamyl amino acids (El-Naggar and Salah 1997).

Glutathione (Y-glutamyl-cysteinylglycine) is a typical amino acid in which the N-terminal glutamate is linked to cysteine via a non-peptidyl bond, is present in all forms of life. In humans and animals, glutathione is required for the action of several enzymes (Lehninger, et al., 1993).

The amino acid cysteine through its active reducing sulphhydryl radicals (-SH) is the effective component of glutathione. This active group has proved its protective function in many toxic states (Yamada et al., 1964; Horiuchi et al., 1979 and Cicchella, 1972). These investigators demonstrated the safety of this compound as a natural body synthesized compound. Even at neoplasms level, a high protective dose of Glutathione administered with the antimitotic agent, cisplatin has rendered the tumor less bulky and easily removed (Fontanelli et al., 1992).

Vitamin $\mathrm{C}$ is not present in all birds' tissues so that it is considered as external antioxidants. It is an available substance, which passes from the plasma into the body tissues, where it plays an important role in liver metabolism, haemopoiesis, collagen formation, endocrine control, ovulation and other metabolic processes. Vitamin C plays an important role in insecticide toxicity 
protection especially in the hepatic toxicity as antioxidant agent and prevents the effect of free radicals for the vital cells (AbdElghaney 2002).

\section{Materials and Methods}

\section{1- Experimental animals:}

A total of 90 male Japanese quails (Coturnix coturnix japonica) were kept under normal laboratory condition.

Birds were divided randomly into equal 6 groups of 20 birds in each, as the following:

Group 1: Control group.

Group 2: Injected with vitamin C $(0.08$ $\mathrm{mg} / \mathrm{kg}$ body weight).

Group 3: Treated with glutathione $(0.55$ $\mathrm{mg} / \mathrm{kg}$ body weight).

Group 4: Treated with 1/50 LD50 imidacloprid.

Group 5: Treated with imidacloprid and vitamin C (1/50 LD50 and $0.08 \mathrm{mg} / \mathrm{kg}$ body weight).

Group 6: Treated with imidacloprid and glutathione (1/50 LD50 and $0.55 \mathrm{mg} / \mathrm{kg}$ body weight).

Birds were orally treated daily with 1/50 LD50 imidacloprid insecticide via stomach tube, the antidotes were used to defense quails against insecticide effect. Vitamin $\mathrm{C}$ and glutathione were used to be antidotes on quails treated with imidacloprid, for 3 and 6 weeks followed by another 3 weeks as recovery periods.

Glutathione was available to be dissolved in water and administrated orally via stomach tube, in a dose equal to 0.55 $\mathrm{mg} / \mathrm{kg}$ of quail.

Birds were scarified at 3 and 6 weeks followed by another 3 weeks as a recovery period. The scarified animals were quickly dissected and small pieces from liver, and testes were rapidly removed and then fixed in $10 \%$ neutral buffered formal for $24 \mathrm{~h}$. Following fixation the specimens were carefully washed in running tap water, dehydrated in ascending series of alcohol, cleared in xylene and then embedded in paraffin wax. Sections of $5 \mu$ thickness were cut and stained with haematoxylin and eosin according to method adopted by Drury and Wallington (1980).

\section{2-Insecticide used:}

Common name: Imidacloprid

Trade name : Gaucho, admir, confidor $20 \%$ EC

Chemical name: 6-chloro-3-pyridnylmethy; 4,5dihydro-N-nitro-0-Himidazol-2-omine

Chemical class: nitro guandine group

Company : Bayer Company Egypt

LD50 : $31 \mathrm{mg} / \mathrm{kg}$ body weight

Dose : 1/50 LD50 daily administration

via stomach tube

Time : 3, 6 weeks of treatment followed by recovery period (3 week)

\section{Results:}

Normal structure of hepatocytes, endothelial lining of the central vein and sinusoidal spaces can be observed in Fig (1), Some degenerative changes could be observed in liver of Japanese quail treated with imidacloprid for 3 \& 6 weeks including highly dilated portal spaces, large degenerated area, faintly stained cells and nuclei Fig (2).

Irregular arrangement of hepatocytes with abnormal architecture, large area of necrosis, dilated sinusoidal spaces, large and small areas of degeneration with faintly stained cytoplasmic nuclei were seen after 3 weeks recovery periods. Figs. $(3,4)$.

Normal well developed hepatocytes, observed in liver of quail injected with vitamin $\mathrm{C}$ for $3 \& 6$ weeks and a recovery period Fig (5) when quail treated with insecticide and vitamin $\mathrm{C}$ for $3 \& 6$ weeks, the liver tissues showed, highly dilated HPV \& hepatic artery and degenerated bile duct, some cells appeared vacuolated (v) with dilated sinusoidal spaces(s). Figs. $(6,7)$. Signs of recovery could be observed after 3-week recovery period with good architecture of hepatocytes. Fig. (8). Liver of Japanese quail treated with glutathione for $3 \& 6$ weeks and 3 weeks recovery showed normal arrangement of hepatocytes as well as, normal portal space. Fig. (9).

Faintly stained hepatocytes, ballooning, (b) enlarged hepatocytes, wide sinusoidal spaces, pyknotic nuclei $(\mathrm{P})$ surrounded by vacuolated cytoplasm, and some affected cells contained karyolytic 


\section{Omiama Soliman Eissa}

nuclei $(\mathrm{K})$ could be observed in quail treated with insecticide and glutathione for 3 and 6 weeks Figs $(10,11)$.

After 3 weeks recovery from treatment with imidacloprid and glutathione marked recovery with normal architecture of hepatocytes, portal space containing normal HPV, artery and bile duct were observed while some hepatocyte appeared vacuolated (v) with signs of ballooning (b) Fig. (12)

The normal histological structure of the testis is shown in Fig. (13). Microscopic examination of testis taken from Japanese quail 3 and 6 weeks following treatment with imidacloprid revealed different degenerative changes included bizarre cells, disappearance of spermatogenetic cells, thickened tunica albuginea, the tubules are devoid of sperms and some pyknotic nuclei could be noticed. No recovery signs could be observed after 3 weeks recovery periods where debris of sperms could be noticed, vacuolation of spermatocytes and rupture of basement membrane could be detected. Figs. (14-15-16).

The treatment of quails with vitamin $\mathrm{C}$ or glutathione alone showed normal appearance.
In testes of japanese quail treated with imidacloprid and vitamin $\mathrm{C}$ for $3 \& 6$ weeks, most of spermatogenetic layers appeared affected, debris of sperms, ruptured basement membrane could be observed. Figs. $(17,18)$ as well as few leydig cells could be seen ,some spermatogenic layers could be observed, some tubules contained sperms.

Noticeable recovery could be detected in group treated with imidacloprid and vitamin $\mathrm{C}$ after 3 weeks recovery peroid.Fig. (19)

Group of quail treated with imidacloprid and injected with glutathione showed mild signs of improvement after 3 and 6 weeks. Appearance of some sperms and mass of undifferentiated cell could be observed while sign of degeneration and vacuolation were still noticed Figs $(20,21)$. While after 3 weeks recovery periods, remarkable recovery was observed where nearly most of the semniferous tubules retained their normal architecture while vacuolation was still observed and some tubules have abnormal arrangement of spermatogenic layers and few leydig cells were appeared Fig (22). 

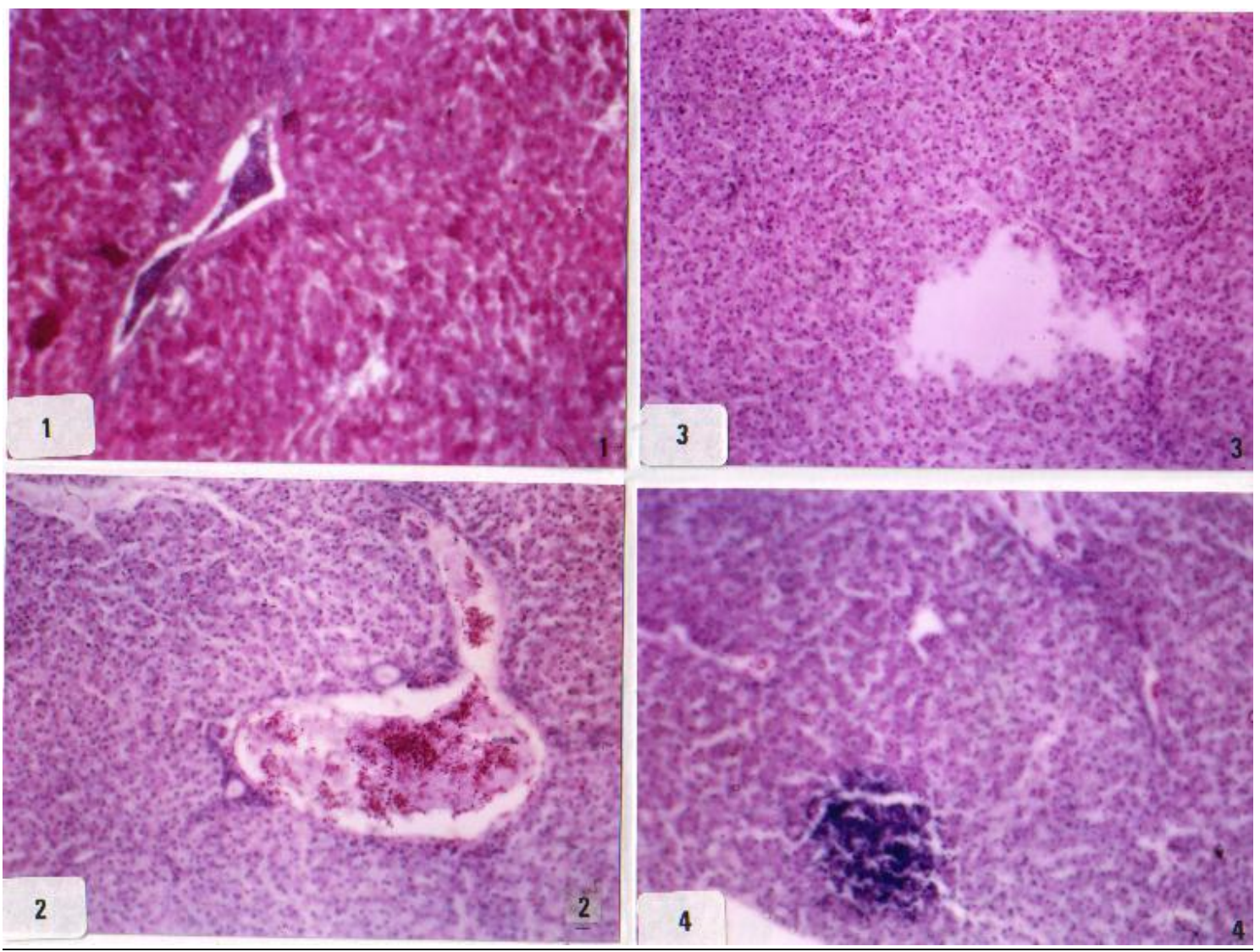

Fig. 1: section in control liver of quail showing normal structure of hepatocytes, endothelial lining of the central vain and sinusoidal spaces.

$(H x \&$ X 250$)$

Fig. 2: section in liver of quail treated with imidacloprid for $3 \& 6$ weeks showing highly dilated portal space, large degenerated area, faintly stained cells and nuclei.

$\left(\begin{array}{llll}H x & \& & X & 250\end{array}\right)$

Figs. 3,4: section in liver of quail treated with imidacloprid after 3 weeks recovery, showing large area of necrosis, dilated sinusoidal spaces, large area of degeneration and faintly stained cytoplasmic nuclei.

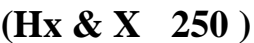




\section{Omiama Soliman Eissa}
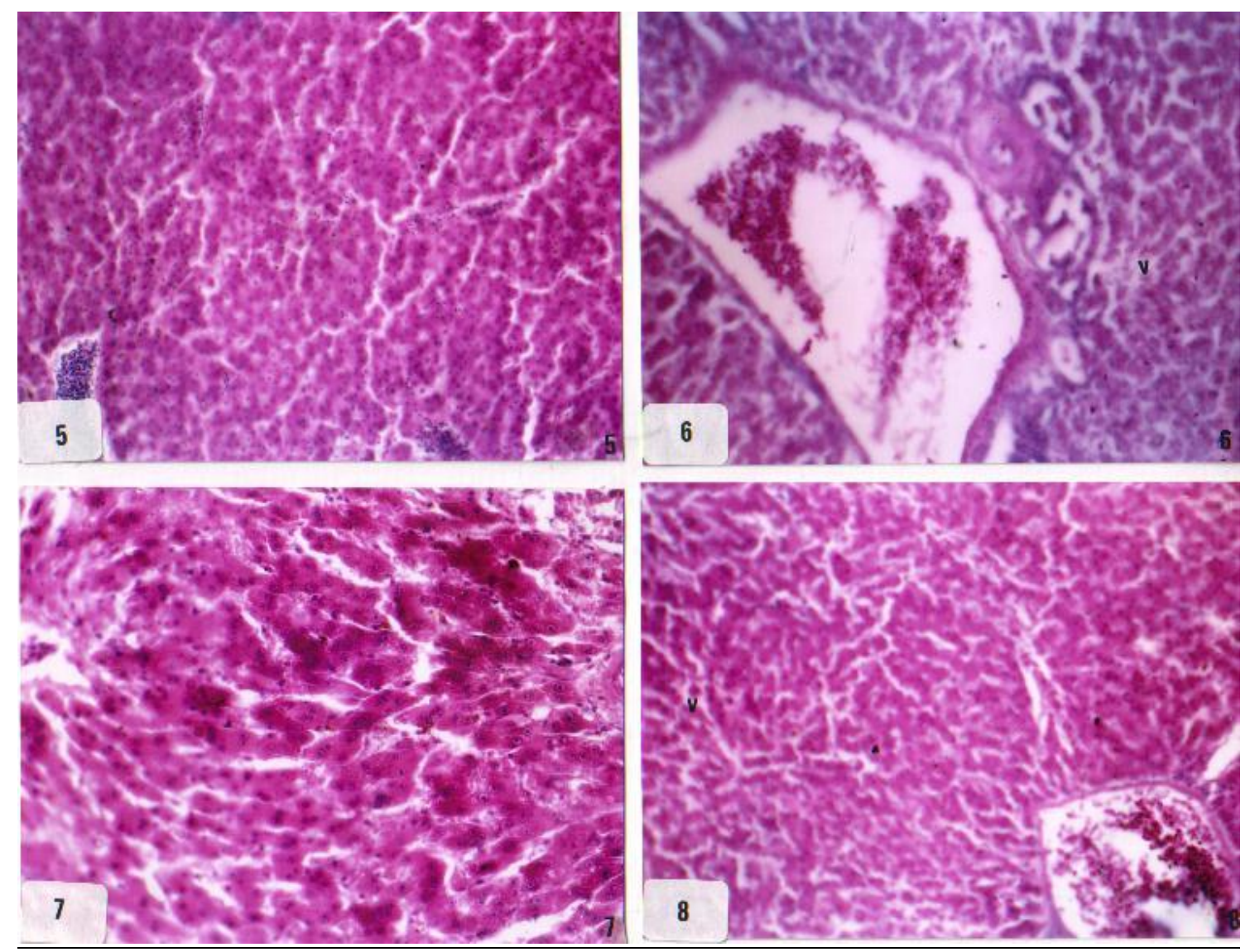

Fig. 5: section in liver of quail treated with vit. $C$ for $3 \& 6$ weeks and recovery period showing normal hepatocytes.

(Hx \& X 250 )

Figs. 6,7: section in liver of quail treated with imidacloprid and vit. $C$ showing highly dilated HPV, hepatic artery and degenerated bile duct, vaculated cells and dilated sinusoidal spaces.

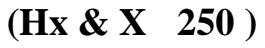

Fig. 8: section in liver of quail treated with imidacloprid and vit. $\mathrm{C}$ after recovery period, showing good architecture of hepatocytes.

$\left(\begin{array}{llll}H x & \& & X & 250\end{array}\right)$ 

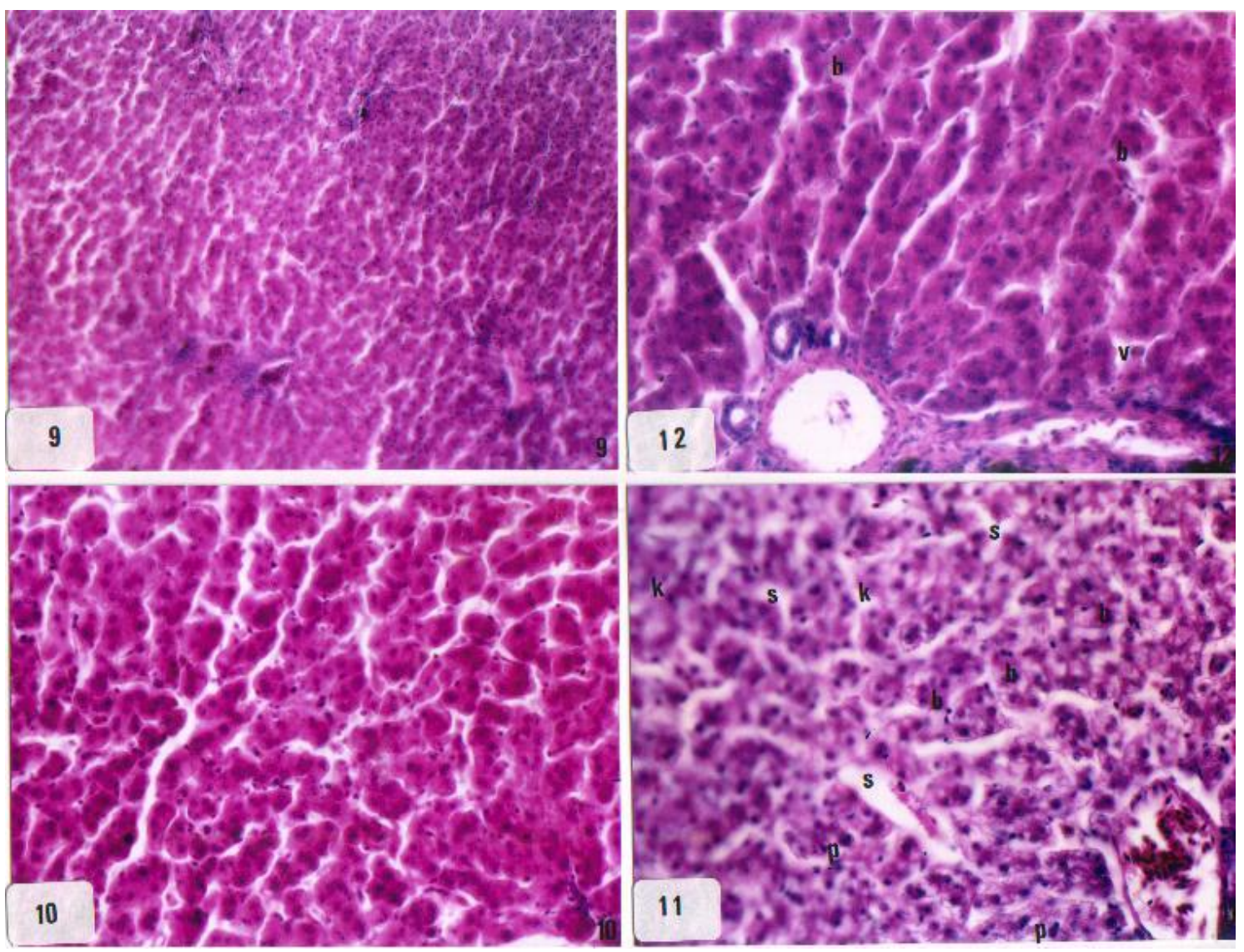

Fig. 9: section in liver of quail treated with glutathione for $3 \& 6$ weeks and 3 recovery weeks, showing normal liver structure.

$(\mathbf{H x} \& \mathbf{X} 250)$

Figs. 10,11: section in liver of quail treated with imidacloprid and glutathione for 3 weeks showing, ballooning, enlarged hepatocytes and faintly stained hepatocytes, wide sinusoidal spaces, pyknotic nuclei, vaculated cytoplasm and nuclei.

$\left(\begin{array}{llll}H x & \& & X & 250\end{array}\right)$

Fig. 12: section in liver of quail treated with imidacloprid and glutathione for 3 recovery weeks showing portal space containing normal hepatic portal vein, hepatic artery and bile duct with some vaculated hepatocytes.

$(H x \&$ X 250$)$ 


\section{Omiama Soliman Eissa}
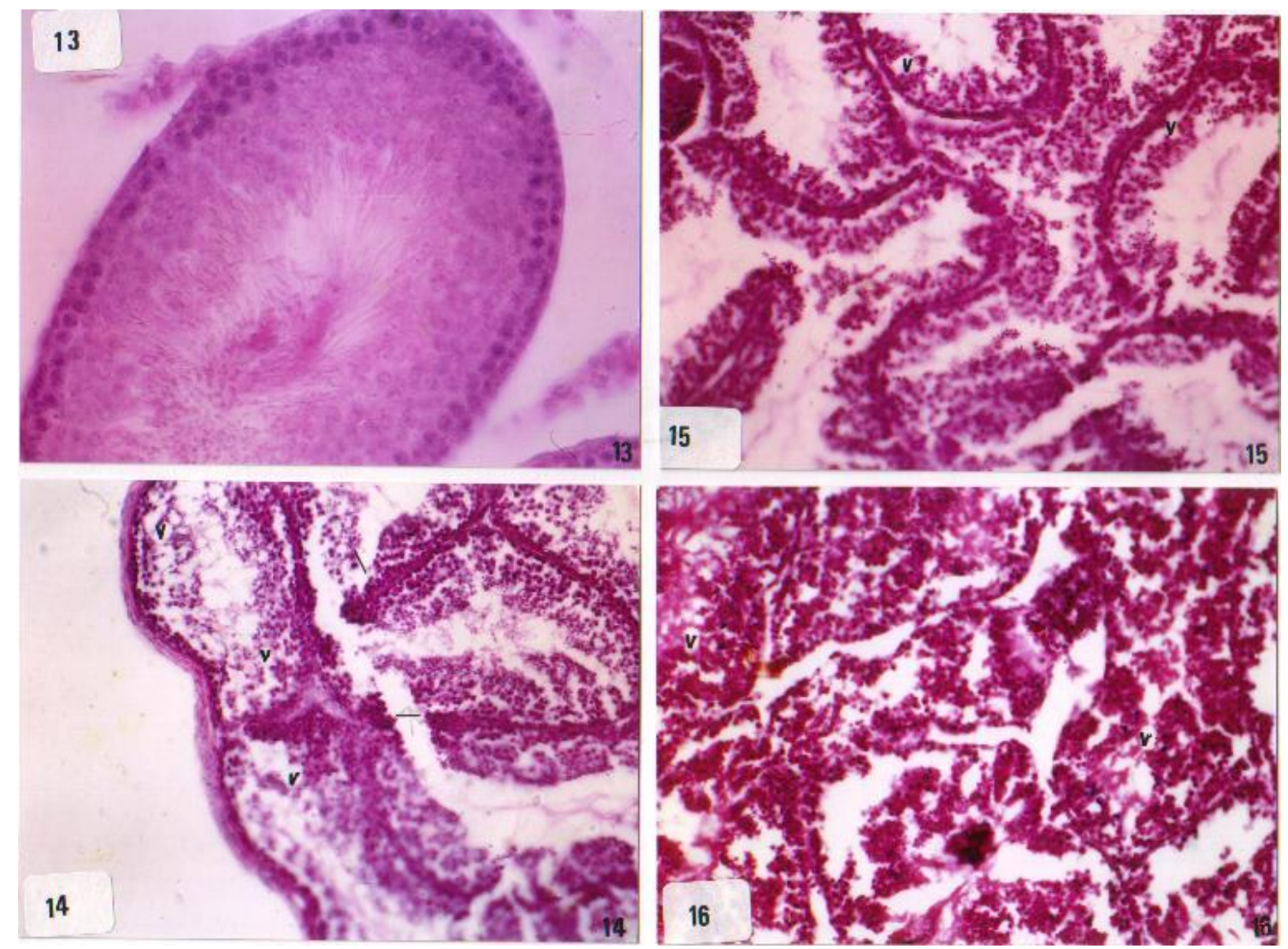

Fig. 13: section in control testis of quail showing normal structure of the testis.

(Hx \& X 250)

Figs. 14,15,16: section in testis of quail treated with imidacloprid for $3 \& 6$ and 3 recovery weeks showing bizarre cells, thickened tunica albuginea, disappearance of spermatogenetic cells. The tubules are devoid of sperms. Some pyknotic nuclei could be observed. Rupture of basement membrane, vacuolation and debris of sperm.

$(H x \&$ X 250$)$ 

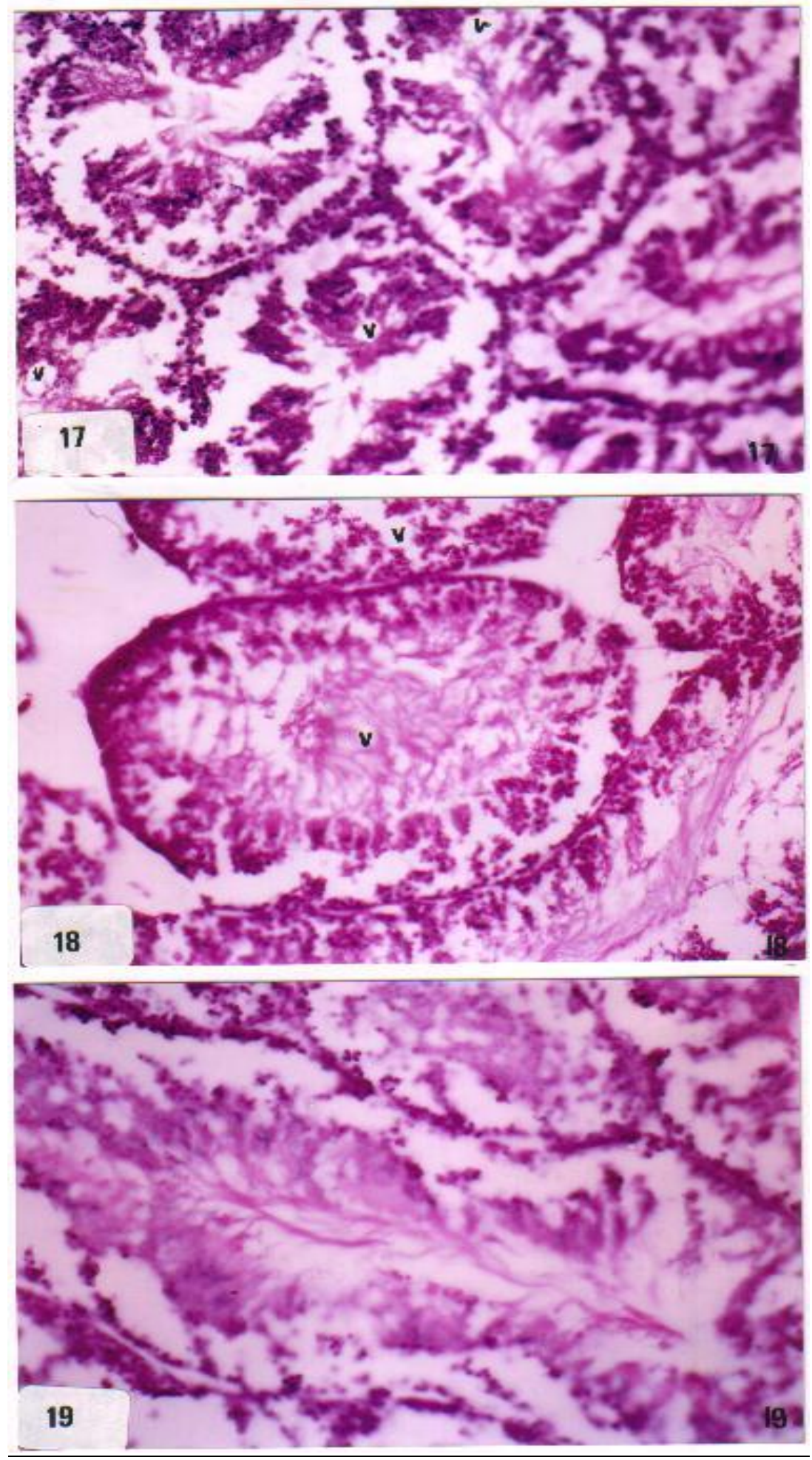

Figs. 17,18,19: section in testis of quail treated with imidacloprid and vit. C for $3 \& 6$ and 3 recovery weeks showing debris of sperms and ruptured basement membrane, few Leydig cells, some tubules contained sperm.

$(H x \&$ X 250$)$ 


\section{Omiama Soliman Eissa}

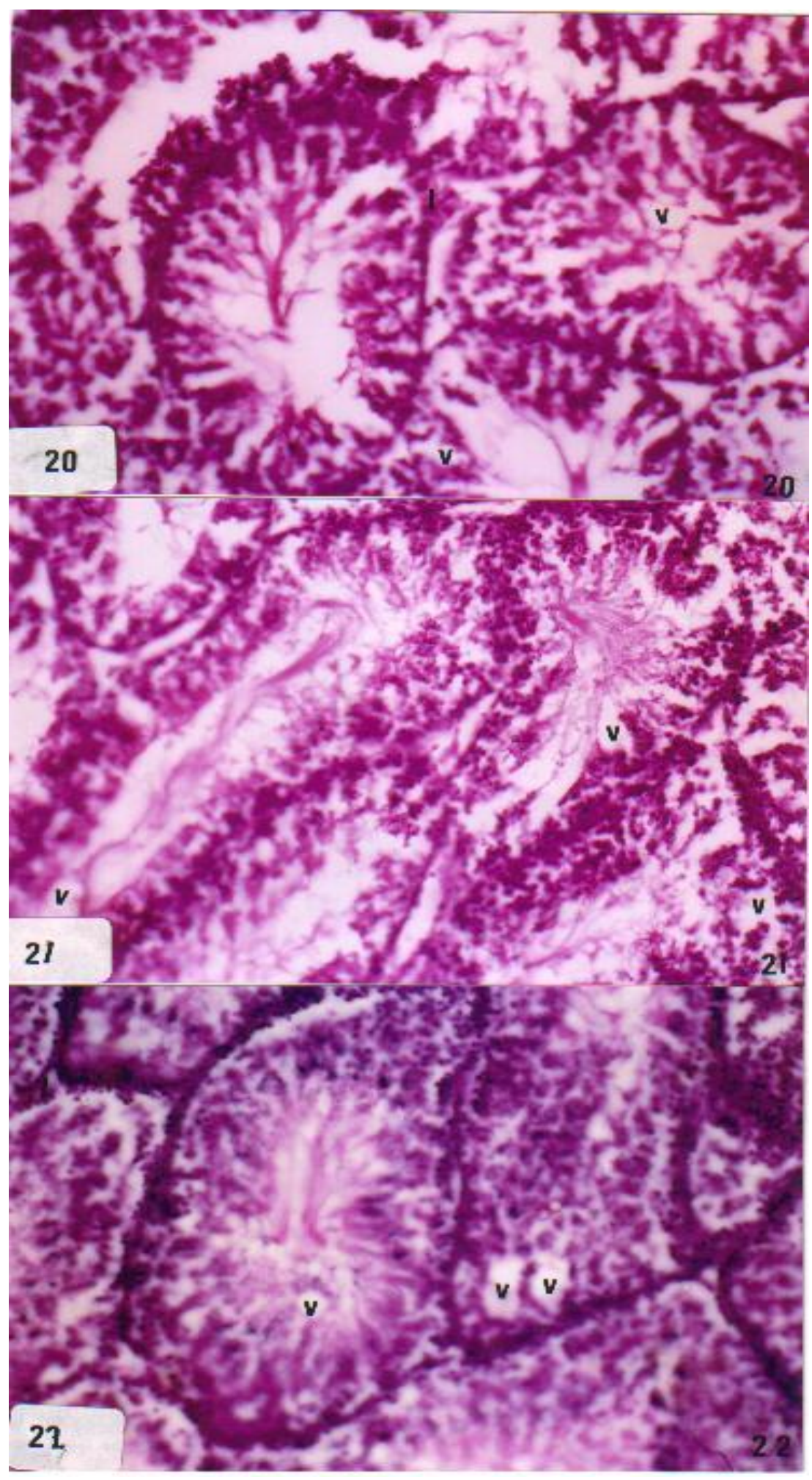

Figs. 20,21: section in testis of quail treated with imidacloprid and glutathione for $3 \& 6$ weeks showing undifferentiated cells, vacuolation and debris of sperms.

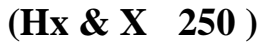

Fig. 22: section in testis of quail treated with imidacloprid and glutathione for 3 weeks recovery showing good architecture, Leydig cells while signs of vacuolation could be detected.

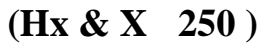




\section{Discussion}

Numerous studies had been performed to demonstrate the effect of insecticides on birds and animals, different pathological changes were noticed in liver and testis of Japanese quail treated with different dose levels, these changes included: large areas of vacuolation, fatty degeneration, large areas of necrosis, congested sinusoidal spaces and different types of affected nuclei. Our results are in accordance with those reported by Abo El-Ezz et al. (1986), El-Sayed (1998), Ahmed, (2000) and ElKhatib et al. (2003).

El-Swak (1990), treated hens with an organophosphorous insecticide profenofos and he noticed that liver showed congestion and degeneration. El-Khatib et al. (2003), observed that liver of treated rats exhibited severe histopathological alteration manifested by kupffer cells activation, necrotic changes in hepatocytes, small focal areas of hepatic necrosis and infiltration with mononuclear cells after treated with butachlor.

Environmental insecticide pollution is considered agreat problem in different countries. Many cases of poisoning have been reported in man, animal and birds fed on diets polluted with such compounds (Kerr et al., 1987). The liver is the major site of metabolism including detoxification and activation of many compounds (Guyton 1995). The present study showed that imidaclopride produced severe structural alteration in hepatocytes and testis of Japanese quail.

Sammour and Hamouda (1997) concluded that Organo-phosphorous insecticides have more or less common toxic effects which are not species specific and therefore are very liable to occur in man if exposed to such compounds.

The swelling and vacuolation of the cells are most probably due to the retention of fluid inside the hepatocytes resulting in what is known as cloudy swelling or hydropic degeneration which is said to be either due to reduction of the energy necessary for regulation of ion concentration of the cells (Elwi, 1967), mild or short term anoxia (Hruban et al., 1972) or metabolic stress (De Duve \& Wattiaux, 1996).

The earliest stage of degeneration in the study is most probably represented in the enlarged distorted hepatocytes which contained deeply stained eosinophilic cytoplasm and deeply stained nuclei in few cells denoting swelling and decreased activity of these cells. Similar cells were described by Abu-Hadeed (1978) in the liver of the Nile fish when exposed to the organophosphorous compound Curacron. However, he attributed them to coagulative necrosis of the cells due to chronic toxicity.

According to Walter\& Israel(1974), cellular infiltration may to be due to the presence of necrotic cells which act as an irritant substance attracting the inflammatory cells.

Mahiuddin \& Ahmed (1986), described bile duct proliferation and attributed it to second grade liver cirrhosis.

Concerning the efficiency of gluthathione in the reduction of toxicity, the study revealed that this biochemical compound has provided protection against imidacloprid toxicity as indicated by improvement of the histological changes and in the serum chemistry of SGOT and SGPT. The explanation of this improvement is linked to the sulphhydryl group of the amino acid cysteine, which prevents oxidation of endogenous mitochondrial, and microsomal enzymes which participate in the toxicity production (Bhanumathi and Devi, 1994).

The liver necrosis is caused by the covalent binding of reactive electrophilic metabolites to liver macromolecules. Normally, these reactive metabolites are detoxified by combining with hepatic glutathione, which when becomes exhausted, the metabolites bind to liver macromolecules which resulted in hepatocytes damage. This biochemical entity has been confirmed by Gardner and Cluff (1970) who stated that hepatic necrosis produced by the ingestion of large quantities of toxic agents can be prevented 


\section{Omiama Soliman Eissa}

or at least attenuated, by the administration of substances such as cysteamine, which bind the electrophilic metabolites and prevent them from reacting with hepatic proteins with resultant hepatic necrosis. Histologically, in this study, glutathione resulted in normal appearance of liver and testis tissues.

Moldeus and Jernstrom (1983), stated that when hepatic tissue is incubated in a medium containing suphhydryl containing amino acids, the hepatic tissue viability would be maintained. Thus, it might be suggested that glutathione protection against tissue toxicity depends on increased glutathione availability. Many authors observed the potency of glutathione in reducing tissue damage when provided prior or even with toxic agents. Bhanumathi and Devi (1994), concluded that not only the suphhydryl group mechanism that protect tissue damage, but glutathione peroxidase enzyme, of which selenium is an integral component, provides a second line of defense. They added that the biochemical action of glutathione seems to be prevention of peroxidative damage to cellular and subcellular elements.

Vitamin $\mathrm{c}$ is a water-soluble antioxidant, which can directly scavenge superoxide and hydroxyl radicals; it is primarily active in the cytosine and plasma (Guyton 1995).

The imidacloprid action potential at the presynaptic ending could be explained by the release of the transmitter of neurons from these pools and binds to receptors on the postsynaptic membrane creating a specific change in the conductivity of the membrane for certain ions. All pre and postsynaptic effects are ultimately due to changes in the permeability of the neural membrane.

The semipermeable membrane of a resting cell is polarized as a result of specific distribution of ions between intra and extra cellular space. The ions responsible for polarization are $\mathrm{Na}+\mathrm{K}+$, $\mathrm{Cl}$ - and sometimes $\mathrm{Ca}++$ (Schroceder and Flattum, 1984).

El-Kashoury (1999), evaluated the effect of imidacloprid at low concentration in male albino rats, either alone or combined with another insecticide as Profenofos or carbosulfan, the obtained results recorded a reduction in liver, kidney function. Also, on cholinesterase activity, total lipids level and no change in plasma glucose level could be noticed. In case of insecticides combination a remarked elevation in glucose level, decrease in ALT and ALP activities, and no change in total protein and albumin could be recorded.

El-Hamady, et.al., (2001), evaluated the effect of imidacloprid insecticide at acute and subacute doses on japanese quail for 30 days. These results showed hepatic and renal toxicity, in addition no haematological, biochemical changes were observed on birds exposed to sublethal doses of insecticide even at the higher tested dose.

From the above-mentioned results, it was clear that the exposure of Japanese quails to the applied insecticide (imidacloprid) caused many histopathological changes in liver and testis. Finally, it is recommended that the use of imidacloprid insecticide must be limited due to its hazardous effect to the non-target species including the farmers and the farm birds even the technicians who exposed to it and also residue in the agricultural products.

Mild recovery was observed in liver and testis treated with vitamin $\mathrm{C}$ and imidacloprid which indicating the antioxidant effect of vitamin C. It's well recommended to use either vitamin $\mathrm{C}$ or glutathione as antioxidants to reduce the toxic effect of imidacloprid.

\section{References:}

1. Abbink, J. (1991): The biochemistry of imidacloprid" Pflanzenschutz-Nachrichten Bayer, 44 (62): 183-195.

2. Abd-El-Ghaney, A. (2002): Study the effect of imidacloprid insecticide on some physiological parameters in Japanese quail. Thesis for M.Sc. Faculty of scienceAlAzhar University for (girls).

3. Abo-El-Ezz, Z. R.; Abd-Allah, G. A.; Hassieb, M. M.; Hassan, G. A. and Salem, M. H. (1986): Histopathological changes due to the effect of organophosphorous and pyrethroid insecticides in rabbits. Alex. J. Vet. Sci., 2 (2): 325-326. 
4. Abu-Hadeed, A. H. (1978): Some toxicological studies of organophosphorous insecticide Curacron to Nilr fish (clarias lazera). Thesis for M. Sc. Faculty of veterinary medicine. Cairo University

5. Ahmed, M. A. (2000): Cytogenetic studies on the effects of certain synthetic Food colours on mice. A thesis submitted to M.Sc degree Faculty of Agricultural AlAzhar University for (girls).

6. Bhanumathi, P. and Devi, P.U. (1994) : Modualtion of glutathione deletion and lipid peroxidation by W R - 777913 and 2 mercaptopropionylglycine in cyclophosphamide chemotherapy.Ind.J.Exp. Biol.,23(8): 562 .

7. Brocksma. A.; Robberts. E. and Saba. F. (1993): "Field trials with confidor (imidacloprid) for the control of various insect species on citrus in the Republic of South Africa: Pflanzenschutz-Nachrichten. Bayer, 46 (64): 25- 32.

8. Ceron, J. J.; Panizo, C. G. and Montez, A. (1995): Toxicological effects in rabbits induced by endosulfan, lindane and methyl parthion representing agricultural by products contamination" Bayer, 48 (66): 105-110.

9. Cicchella, G. (1972): Prevention of occupational mercury poisoning by 2mercaptopropionylgcine. Proc. Soc. Internatl. Symposium on Thiola (Santen Pharmaceutical Co., Osaka, Japan, ed.) 254.

10. De. Duve, C. and Wattiaux, R. (1996): Functions of lysosomes. Ann. Rev. Physiol. 28: 445.

11. Dennis, E.; M. Hitchinson,S.E. and Ewald, H. D. (2000): "Inhibition of immature clenocephalides felis (siphonaptera: pulicidae) development in the immediate environment of cats treated with imidacloprid:. J. of Med. Entom. 37 (2): 228-230.

12. Dieher, H. J.; Gallenkam, P. B.; Jelick. K.; Lantzsch, R. and Shiokawa. K. (1991): 'Synthesis and chemical-physical properties of the insecticide imidacloprid (NTN 33893)" Pflanzenschutz-Nachrichren Bayer. 44 (2): 107-112.

13. Drury, R. A. B. and Wallington, E. (1980): Carleton,s histological technique, 5th edn., London, Oxford University Press, New York, Toronto.

14. El-Hamady. E. S.; Salama,A.E. and N. A. Helal (2001): Toxicological effects of certain biorational insecticides on Japanese (coturinx coturinx japonica) The Animal meeting of the Egyptian society toxicology: 29-30.

15. El-Kashoury, I. A. (1999): Subchronic toxicity studies of imidacloprid, profenofos and carbosulfan and their mixtures on albino rats. Ph.D. Thesis Fac. of Agric. Cairo, Univ.

16. El-Katib, E. N.; Aboul-Enein, A. M and Abdel Aziz, M. M. (2003): Sublethal effects of combined exposure of two herbicides on the male white rat. Histological studies. The 27th conference of the Egyptian Society of histology and cytology.

17. El-Naggar, M. M. and Salah, E. F. (1997): Light and electron microscopic studies of the protective effect of glutathione on antibilharizial drug induced hepatic and renal toxicity in adult albino rats. Egypt. J. Histol. 20 (1): 121-134.

18. El-Sayed E. S. (1998): Effect of malathion insecticide on productive and reproductive performances in Japanese quail. Thesis for M.Sc. Faculty of agriculture Al-Azhar University.

19. El-Swak, A. A. (1990): Histopathological changes due to the effect of organophosphorous insecticide profenofos in hens. Egypt. J. Comp. Clin. Path., 3 (1): 139-148.

20. Elwi, M. A. (1967): Text book of pathology, 2nd edn., 523 Saunders Company. Philadelphia and London.

21. Fontanelli, R.; Spatti, G.; Raspagliesi, Zunion, F. and Di-Re, F. (1992): A preoperative single course of high-dose cisplatin and bleomycin with glutathione protection in bulky stage IP/II carcinoma of the cervix. Annals of Oncology 3 (2): 117.

22. Gardner, P. and Cluff, L. E. (1970): The epidemiology of adverse drug reactions: A review and prespective. Johns Hopkins Med. J. 126: 77.

23. Guyton, A. C. (1995): Textbook of Medical Physiology. 13rd edn., W. B. Saunders Company. Philadelphia and London.

24. Horiuchi, M.; Takase, K.; Nomura, M. and ciba, T. (1979): Effect of thiola compound experimental liver damage induced by carbon tetrachloride. Nippon. Yakurigaku. Zasshi 75 (5): 433.

25. Hruban A.; Swift, H.; Dunn, F. W. and Lewis, D. E. (1972): Microbodies constituent organelles of animal cells. Lab. Invest., 27: 184.

26. Hutchinson, M. J.; Jacobs, D. E. and Mencke. N. (2001): "Establishment of the 


\section{Omiama Soliman Eissa}

cat flea (Ctenocephalides felis felis) on the ferret (Mustela putorius furo) and its control with imidacloprid" Med. Vet. Entomol. 15 (2): 212-214.

27. Kerr, L. A.; Huson, L. M. and Osborn, R. G. (1987): Organophosphate toxicosis in Brangus heifer. Vet. Medicine. 82 (7): 729.

28. Kutches, A. J.; Church, D. C. and Duryee, F. L. (1970): "Toxicological effects of Pesticides on rumen function"in vitro". J. Agric. Food. Chem., 18: 430-433.

29. Lehninger, A. L.; Nelson, D. L. and Cox, M. M. (1993): Principles of biochemistry, the molecular basis and cell structure and function 2nd ed. Worth publishers, Inc., New York.

30. Li burd, O. E.; Holley, T. C. and Moses, A. L. (2004): Toxicity of imidacloprid treated spheres to caribbean fruit fly. J. Econ Entomol. 97 (2), 525-529.

31. Matsumura, F. (1985): Toxicology of insecticides. 2nd Ed., Plenum Press, New York, PP. 267-270.

32. Moldeus, P. and Jernstorm, B. (1983): Functions of glutathione eds: IarssonA, Orrenius S, Holmgren A and Mannervik B. Raven Press. New York.

33. Mohiuddin, S. M. and Ahmed, A. N. (1986): effect of feeding Ekalux (Quinolphos) pesticide in poultry. Indian Vet. J. (63) 10: 796.

34. Pfluger. W. and Schmuch. R. (1991): " Ecotoxicological profile of imidacloprid. Plfanzenschutz-Nachrichten". Bayer. 44 (2): 145-158.

35. Philippe, J.; Buronfosse, F. and Videmann., B. (1999): "Evaluation of the toxicity of imidacloprid in wild birds. A new high performance thin layer chromatography (HPTLC) method for the analysis of liver and crop samples in suspected poisoning cases" J. of liquid chromatography \& related technologies. 22 (10): 1547-1559.

36. Sammour, A. B. and Hamouda, M. H. (1997): Effect of the organophosphorous insecticide "primiphos-methyl" on the liver of adult female albino rats. Egypt. J. Histol. 20 (1): 57-77.

37. Schroceder, M. E. and R. F. Flattum (1984): The mode of action and neurotoxic properties of the nitromethylene heterocycle insecticides". Pest. Bioch. Physiol. 22: 148-160.

38. Shull, L. R. and Coheeke, P. R. (1983): Effect of synthetic and natural toxicants on livestock. Anim. Sci., 75: 330-353.

39. Soloway, S. B.; Henry A.C.; Kollmeyer W. D.; Padget,W.M; Powell, J.E.; Roman, C. H.; Tieman.; R. A. and Horn,C.A.; (1978): Nitromethylene insecticides, In Advances in Pesticide science, Part 2, H. Geissbuhler, G. T. Brooks and P. C. Kearney (Eds., Oxford, Pergamon Press, 206-217).

40. Walter, J. B. and Israel, M. S. (1974): General pathology, 4th edn., Churchill Livingestone, Edinburgh, London, New York

41. Yamada, R.; Ishio, M.; Doi, I. and Iakegawa, S. (1964): Clinical experience with alpha-mercapto-propionly glycine for the treatment of liver diseases. Jap. J. Clin. Exp. Med. 41: 1059.

42. Zafeiridon, $\mathbf{G}$ and Theophilids, G. (2004): The action of the insecticide imidacloprode on the respiratory rythan of an insect. Neuro. Sci. lett., 29: (3) 205-209 
التأثير الوقائي لفيتامين ( ج ) والجلوتاثيون على التخيرات المرضية النسيجية التي يحثثها ألمبيد الحشري ( اميداكلوبريد ) في كبد وخصية الفئئ السمان الياباني

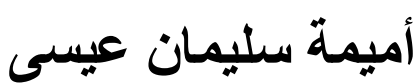 \\ المركز القومى لبحوث وتكنولوجيا الإشعاع ـهيئة الطاقة الذرية
}

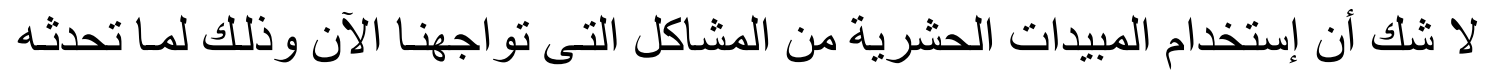

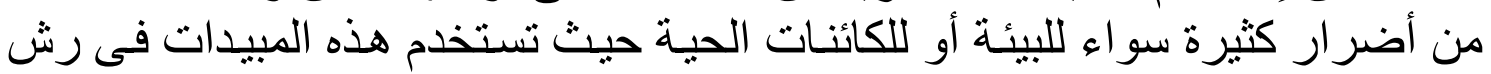

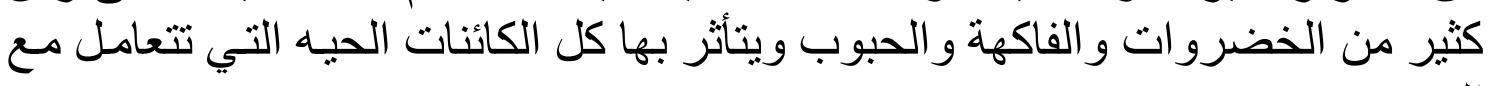
البيئه.

ويطالعنا العلماء يو ميا بإكتشاف مبيد جديد حيث تتطور قدرة الحشر ات الضـارة

و الفطريات على مقاومة كثير من المبيدات القديمة وتكتسب مناعة ضئس ضدها.

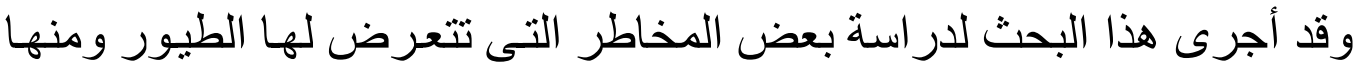

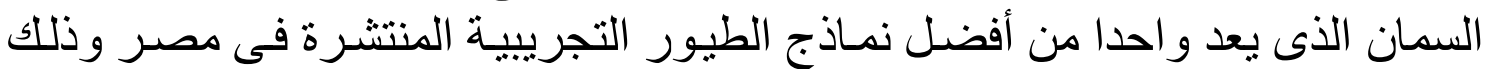

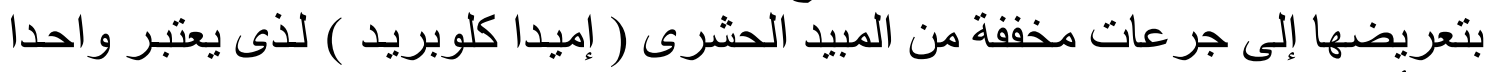

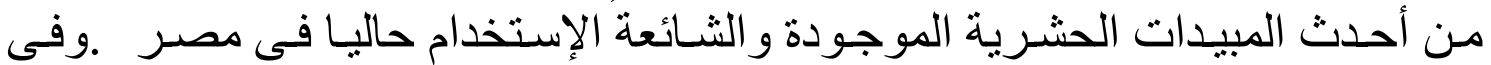

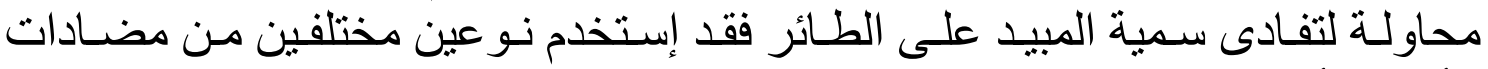

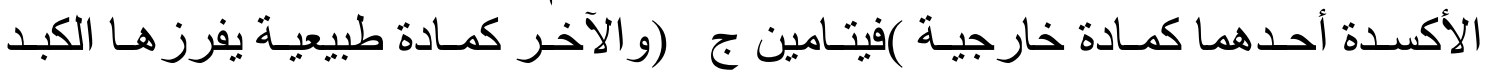

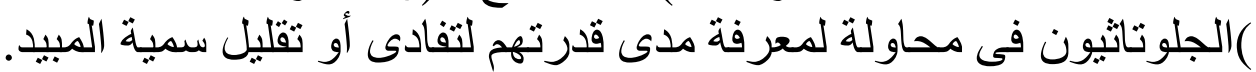

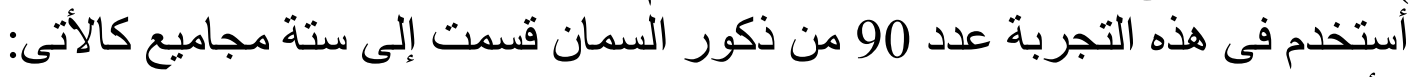

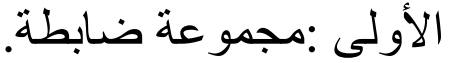

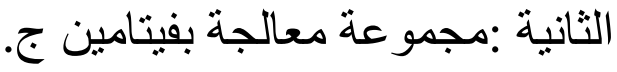

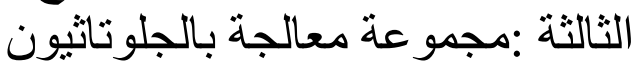
الر ابعة : مجمو عـة معالجـة بجر عـة 50/1 من الجركة عـة النصف مميتـة للمبيد الحشرى أميداكلوبريد.

الخامسة :مجمو عة معالجة بالمبيد الحشرى أميداكلوبريد بالإضافة إلى فيتامين ج.

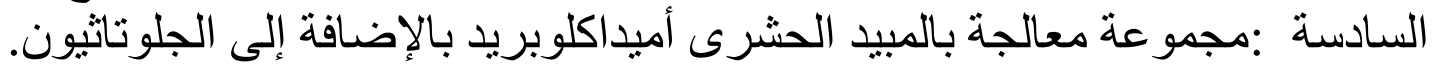

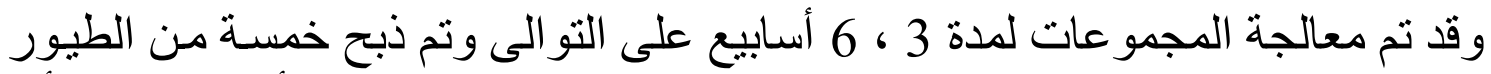

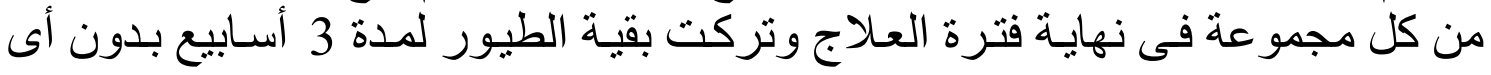
معالجة كفترة إستشفاء.

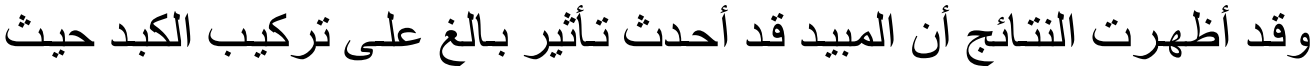

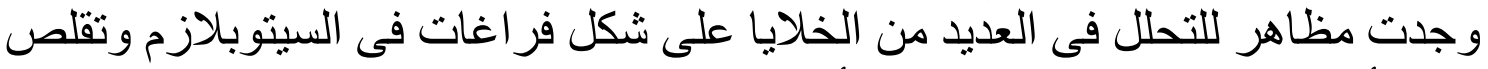

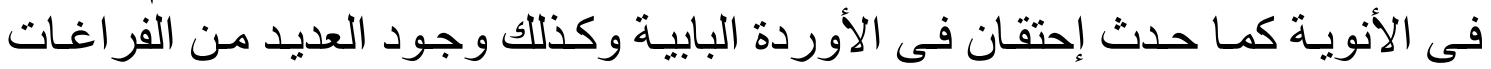

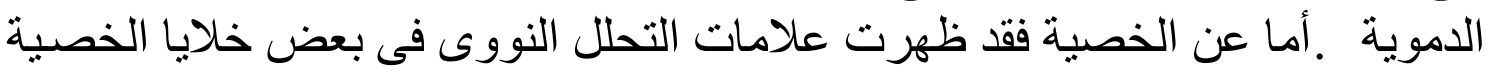




\section{Omiama Soliman Eissa}

كما ظهرت بعض تجمعات من النفايات الخلوية فى البعض الأخر من الخلايا وخاصـة خلايا لايدج.

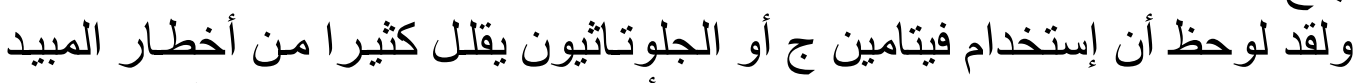

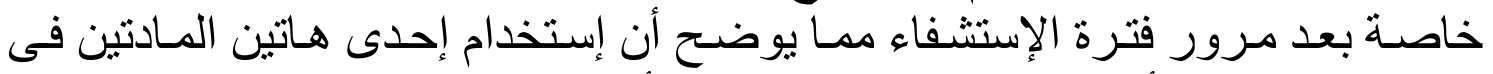

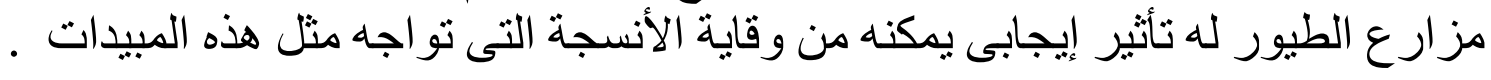

